\title{
PEMBERANTASAN TINDAK PIDANA KORUPSI DAN DIMENSI SISTEMATIK HUKUM KHUSUS
}

\author{
Oleh: Nopsianus Max Damping \\ nomad_patners@yahoo.co.id \\ Universitas Kristen Indonesia, Jakarta, Indonesia
}

\begin{abstract}
The legal politics of eradicating corruption in Indonesia has long been applied. This can be traced through a track record that begins with enforcement corruption eradication regulations around 1950, even then still in a limited scope, but at least in it has begun awareness arises about the importance of efforts to eradicate corruption. The rules on combating corruption rst appeared through regulations Ruler of War from Army Chief of Staff on April 16, 1950. No.Prt / Peperpu /013/1958, and from the Navy Chief of Staff on April 17 1958. No.Prt /Z.I/17. June 9, 1960. Second rule from the authorities this war, was later declared declared a Government Regulation In lieu of Law No. 24 Know 1960 about "Investigations, Prosecution, Corruption Investigation. Then there was reform welcomed by the community, and all components of the nation, to encourage a thorough renewal in the legal eld, and the government immediately undertook Amendments to a number of laws and regulations - especially regulations who took part in $K K N$, and one of them was the Law concerning Eradication of Corruption, Law No. 31 of 1999 concerning Eradication of Corruption Crime.
\end{abstract}

Keyword: corruption crime; eradicating corruption; legal politics; KKN.

\section{Pendahuluan}

Organisasi Transparansi Internasional, menyebutkan bahwa korupsi merupakan "perilaku pejabat publik, baik politisi maupun pegawai negeri, yang secara tidak wajar dan tidak legal memperkaya diri atau memperkaya mereka yang dekat dengannya, dengan menyalahgunakan kekuasaan publik yang dipercayakan kepada mereka." 1

Sikap tak kuasa menolak godaan hidup mewah dan hasrat cepat kaya tanpa kerja keras, berjualan tanpa kejujuran dan suka melakukan kecurangan, merupakan penggalan dari rentetan dan ciri khas gaya hidup sang koruptor. Selain itu, sikap masa bodoh, gemar memamerkan harta dan tidak mau peduli dengan hak dan kepentingan orang lain, akan selalu terpantul melalui pola kehidupan sang koruptor dalam setiap denyut aktifitas kesehariannya.

Mahatma Gandhi, pernah mengingatkan dan berkata bahwa; "there are seven sins in the world: Wealth without work, Pleasure without conscience, Knowledge without character, Commerce without morality, Sciense without humanity, Workship

\footnotetext{
1 Mohammad Amien Rais, "Agenda-Mendesak Bangsa Selamatkan Indonesia!.” PPSK Pres, Cetakan Ketiga, Yogyakarta, 2008, hlm.177
}

without sacrifice, and Politics without principle." (ada tujuh macam dosa di dunia: Kekayaan tanpa kerja, Kesenangan tanpa nurani, Pengetahuan tanpa watak, Perdagangan tanpa moralitas, Ilmu tanpa kemanusiaan, Ibadah tanpa pengorbanan, dan Politik tanpa prinsip). ${ }^{2}$

Masalah-masalah korupsi, sebetulnya sudah merupakan isu lawas di negeri ini. Mental dan sikap aji mumpung sudah lama digunakan sebagai jurus pamungkas untuk selalu meraup keuntungan pada setiap kesempatan yang tidak boleh dilewatkan begitu saja. Bahkan seorang pejabat akan dianggap "bodoh dan tidak kreatif" oleh kalangan dekatnya, apabila tidak dapat memanfaatkan situasi dan kesempatan yang ada didepan mata. Mental aji mumpung ini kemudian membudaya dan berkembang dikalangan oknum-oknum pegawai negeri, para oknum pejabat negara maupun oleh mereka yang ketiban mendapatkan promosi dan kesempatan untuk menduduki jabatan-jabatan publik.

Selain itu sejarah juga mencatat bahwa kebiasaan aji mumpung ini, tidak pernah lapuk oleh zaman, aksi ambil untung tanpa hak ini, terus berlangsung dari generasi ke generasi. Praktek-praktek korupsi

2 Ibid, hlm. 173 
seperti ini, terus bertumbuh subur dan sepertinya tanpa ada perasaan bersalah dari sang pelaku. Kelakuan koruptifnya terus bergulir baik semasa pemerintahan orde lama (ORLA 1945-1966), kemudian orde baru (ORBA 1966-1998) maupun dimasa reformasi (1998 sampai sekarang).

Potret sejarah terhadap politik hukum pemberantasan korupsi, telah lama diterapkan. Hal ini dapat kita telusuri melalui rekam jejak yang diawali dengan pemberlakuan peraturan pemberantasan korupsi pada sekitar tahun 1950, sekalipun ketika itu masih dalam ruang lingkup terbatas, namun paling tidak, didalamnya sudah mulai timbul kesadaran mengenai pentingnya melakukan upaya pemberantasan korupsi.

Aturan tentang pemberantasan korupsi justru pertama kali muncul melalui Peraturan Penguasa Perang dari Kepala Staf Angkatan Darat tanggal 16 April 1950 No. Prt/Peperpu/013/1958 dan dari Kepala Staf Angkatan Laut tanggal 17 April 1958 No. Prt/Z.I/17, tanggal 9 Juni 1960. Kedua Peraturan dari Penguasa Perang tersebut, kemudian dinyatakan sebagai Peraturan Pemerintah Pengganti Undangundang dengan No. 24 tahun 1960, mengenai "Pengusutan, Penuntutan, Pemeriksaan Tindak Pidana Korupsi. ${ }^{3}$

Praktek yang sama sekali tidak terpuji ini, dalam potret Indonesia kekinian, dari tahun ke tahun bukannya semakin menurun (berkurang), melainkan tetap eksis dan menggoda, bahkan semakin bervariasi dan bertumbuh ke-arah presensi peningkatan yang cukup signifikan, baik diukur dari segi kuantitas maupun kualitasnya. Korupsi pada masa kini, hampir pasti telah menjadi sebuah pilihan gaya hidup kosmopolit, tanpa perasaan malu, ini jelas sangat mengerikan dan yang pasti akan mengancam eksistensi berbangsa dan bernegara.

Data hasil survei yang dilakukan secara independen dan transparan oleh Transparansi International terhadap 102 negara di dunia pada tahun 2002, menyebutkan Indonesia justru ditempatkan pada urutan ke-4 sebagai negara terkorup di dunia. ${ }^{4}$

\footnotetext{
3 Indriyanto Seno Adji, "Korupsi Kebijakan Aparatur Negara \& Hukum Pidana, Diadit Media, Yakarta, 2007, hlm.6

4 Berdasarkan urutannya: Banglades, terkorup; Nigeria, urutan kedua; Paraguay, Anggola dan Madagaskar, di urutan ketiga; Kenya dan Indonesia, diurutan keempat. Lihat Kompas, 9 Maret 2003, Ketika China Perangi Korupsi, hlm.30.
}

Penilaian dan stigma korupsi tersebut diatas, tentu saja sangat memalukan dan memprihatinkan kita selaku bangsa Indonesia. Para investor asing, satu demi satu dan lambat laun namun pasti akan menjauh dari bumi Indonesia, karena mereka para investor tidak akan nyaman dan mampu bertahan dengan situasi ekonomi biaya tinggi. Disamping itu, bila dilihat dari aspek kepentingan ekonomi dan politik, hal yang paling menyedihkan ialah korupsi sudah mulai memukul ketahanan bangsa serta merendahkan harkat dan martabat seluruh masyarakat dan pemerintah Indonesia baik dalam kancah pergaulan regional maupun internasional.

Perasaan miris dan keprihatinan yang mendalam, walhasil dikemukakan Romli Atmasasmita, ${ }^{5}$ bahwa "masalah korupsi (pen: di Indonesia) sudah merupakan ancaman serius terhadap stabilitas, keamanan masyarakat nasional dan internasional, telah melemahkan institusi, nilai-nilai demokrasi, nilai-nilai keadilan serta membahayakan pembangunan berkelanjutan dan penegakan hukum. Pernyataan ini sudah merupakan prinsip umum hukum internasional dalam pencegahan dan pemberantasan korupsi."

Ungkapan senada juga dituturkan, Barda Nawawi Arief, ${ }^{6}$ bahwa "tindakan korupsi merupakan salah satu masalah besar yang selalu menjadi sorotan dan sekaligus keprihatinan masyarakat. Tidak hanya menjadi keprihatinan nasional tetapi juga keprihatinan dunia internasional."

Jika dipandang dari perspektif internasional, tindakan korupsi dapat diklasifikasikan sebagai salah satu kejahatan dalam white collar crime yang membawa dampak akibat yang sangat kompleksitas. Masalah korupsi ini sudah menjadi perhatian yang serius dari masyarakat internasional. Resolusi tentang "Corruption in government" yang diterima Kongres PBB ke-8 mengenai "The Prevention of Crime and the Treatment of Offenders" di Havana (Cuba) tahun 1990, antara lain dinyatakan bahwa:

Korupsi dikalangan pejabat publik (corrupt activities of public official) :

\footnotetext{
5 Romli Atmasasmita, "Strategi dan Kebijakan Hukum Dalam Pemberantasan Korupsi Melawan Kejahatan Korporasi di Indonesia: Membentuk Ius Constituendum Pasca Ratifikasi Konvensi PBB Menentang Korupsi Tahun 2003." (Paper), Jakarta 2006, hlm. 1

6 Barda Nawawi Arief, "Beberapa Aspek Kebijakan Penegakan dan Pengembangan Hukum Pidana. "Citra Aditya Bakti, Ceta- kan II, Semarang, 2005, hlm.97
} 
a. Dapat menghancurkan efektivitas potensial dari semua jenis program pemerintah (can destroy the potential effectiveness of all types of governmental programmes)

b. Dapatmengganggu/menghambatpembangunan (hinder development); dan

c. Menimbulkan korban individu maupun kelompok masyarakat (victimize individuals and groups)

d. Ada keterkaitan erat antara korupsi dan berbagai bentuk kejahatan ekonomi, kejahatan terorganisasi dan pencucian uang haram (money laundering). ${ }^{7}$

Opini masyarakat internasional dan ungkapan keprihatinan para pakar yang berkaitan dengan perilaku korupsi diatas, maka yang menjadi pertanyaannya adalah mengapa seseorang dapat berperilaku koruptif. Robert Klitgaard, ${ }^{8}$ secara gamblang dan sederhana menyebutkan bahwa : “.... action plans often stops at calls for moral renovation, codes of conduct, or new law. By themselves, these measure accomplish little. Oleh karenanya perlu dipahami bahwa, "corruption is a crime calculation, not passion”, sehingga dapat dirumuskan melalui susunan variabel simbolik, sebagai berikut :$$
\mathrm{C}=\mathrm{D}+\mathrm{M}-\mathrm{A}
$$$$
(\text { Corruption }=\text { Discretion }+ \text { Monopoly }-
$$ Accountability).}

Berdasarkan postulat susunan variabel tersebut, Klitgaard hendak mengingatkan dan menyampaikan bahwa fenomena terjadinya korupsi lebih disebabkan oleh faktor adanya monopoli kekuasaan (kewenangan) yang besar ditambah dengan dominasi kebijakan diskresi, namun tidak disertai dengan kewajiban akuntabilitas dalam

$$
\text { Ibid, hlm. 97-98. }
$$

\section{Robert Klitgaard, "Corrupt Custom”,} sebagaimana dikutip Mardjono Resodiputro, Tanggapan Atas Kajian Laboratorium Sosiologi FISIP-UI tentang "Performance Review" atas Tim Gabungan Pemberantasan Tindak Pidana Korupsi (TG-TPK), Catatan diskusi disampaikan dalam Seminar Tim Gabungan Pemberantasan Tindak Pidana Korups, yang diselenggarakan oleh Laboratorium Sosiologo FISIP-UI, Jakarta 25 Juli 2001. menjalankan fungsi tugas/ jabatan.

Bertolak dari hipotesis diatas, maka secara sederhana kita dapat simpulkan bahwa pada dasarnya korupsi dapat terjadi dimana dan kapan saja. Paling tidak ada tiga hal mendasar, yaitu adanya diskresi dan monopoli kewenangan serta minus akuntabilitas. Disamping ketiga faktor mendasar ini, tentu saja masih ada banyak faktor penyebab lain yang menjadi dasar dan alasan mengapa seseorang melakukan korupsi.

Satu diantaranya menyangkut tingkat kesadaran pejabat dalam menjalankan tugas dan tanggung jawab dibidang pemerintahan masih sangat rendah. Selain itu fungsi pengawasan oleh aparat berwenang maupun oleh masyarakat dalam fungsi checks and balances juga terasa masih sangat minim.

Situasi dan kondisi yang demikian, lambat laun akan membuka rentang peluang dalam kesempatan untuk melakukan penyimpangan kewenangan oleh para pelaku dan kelompoknya. Momentum seperti inilah yang kemudian kerap digunakan, baik oleh oknum pejabat ditingkat pusat maupun oknum para pejabat di daerah.

Voltaire, pernah mengatakan bahwa "manusia harus memiliki sifat korupsi sedikit, karena mereka tidak terlahir sebagai serigala, namun mereka akan menjadi serigala." Oleh karenanya jenjang pengawasan terhadap para pemangku kekuasaan dalam hal ini pemerintah, mutlak diperlukan guna memperkecil penyimpangan kekuasaan yang ada padanya.

Ketika terjadi pertarungan kepentingan kekuasaan, eskalasi politik Indonesia pun memanas pada sekitar pertengahan tahun 1998, dinamika gerakan massal reformasi berlangsung secara cepat dan sistimatis. Klimaksnya memaksa Soeharto lengser dari kekuasaan (1998), maka dengan sendirinya orde baru (ORBA) pun tumbang. Agenda tuntutan reformasi ketika itu hanya terfokus pada dua hal yakni menurunkan Soeharto dan segera melakukan pemberantasan Korupsi, Kolusi dan Nepotisme (KKN) disemua lini dan bidang pemerintahan.

Agenda awal reformasi tersebut membawa angin segar, disambut antusias oleh masyarakat dan seluruh komponen bangsa. Hal ini kemudian mendorong Pemerintah untuk segera melakukan reformasi dan pembaharuan menyeluruh dibidang hukum dan pemerintahan, diantaranya segera 
melakukan perubahan terhadap sejumlah peraturan perundang-undangan, terutama peraturan-peraturan yang menyangkut pemberantasan KKN dan salah satunya adalah Undang-undang tentang Pemberantasan Tindak Pidana Korupsi.

Dengan kata lain, Pemerintah didorong untuk secepatnya melakukan berbagai pengkajian, reorientasi dan re-evaluasi terhadap fungsi dan efektifitas Undang-undang Pemberantasan Tindak Pidana Korupsi (Undang-undang No. 3 tahun 1971) sebagai sarana dan perangkat regulasi hukum dalam memberantas dan menanggulangi masalah-masalah korupsi di Indonesia. Diketahui bahwa ketentuan dalam Undang-undang No. 3 tahun 1971 tentang Pemberantasan Tindak Pidana Korupsi, dipandang terlalu banyak menyimpan kelemahan, ketinggalan zaman (usang) dan tidak lagi memadai untuk dipertahankan. Undang-undang tersebut terbukti tidak mampu menjerat koruptor kelas kakap, karena selalu kalah cepat dalam menemukan dan mengumpulkan alat-alat bukti. Hal ini tentu saja akan membawa konsekuensi pada kesulitan penuntut umum dalam melakukan pembuktian penuntutannya di pengadilan. Oleh karenanya, maka dipandang perlu agar Undang-undang Pemberantasan Tindak Pidana Korupsi (Undang-undang No. 3 tahun 1971) untuk segera diganti dengan Undang-undang baru yang diharapkan akan dapat lebih maksimal, lebih memadai, berdaya guna dan berhasil guna dalam melakukan pemberantas tindak pidana korupsi.

Senada dengan hal tersebut diatas, Roscoe Pound, ${ }^{9}$ menyatakan bahwa "law must be stable and yet it cannot stand stiil. "Bahwa perkembangan dalam masyarakat memang menjadi titik tolak dari keberadaan suatu peraturan. Hukum yang stabil akan dapat menjadi ukuran yang pasti bagi masyarakat untuk menentukan perbuatan mana yang boleh dan perbautan mana yang tidak boleh. Namun demikian harus pula diakui bahwa hukum yang berjalan ditempat seperti itu dalam kenyataannya akan menjadi hukum yang cepat usang dan pada gilirannya akan tertinggal jauh oleh kemajuan masyarakat.

Selain diawali semangat dibentuknya Undangundang No. 31 tahun 1999 tentang Pemberantasan Tindak Pidana Korupsi tersebut diatas, sejarah juga mencatat bahwa dasar dan alasan pembentukan

9 Roscoe Pound, “Interpretation of Legal History”, Wm. W. Gaunt \& Sons Inc, Florida, 1986, hlm.1
Undang-undang No. 31 tahun 1999, mulanya ditandai dan tidak terlepas dari peranan dan Ketetapan Majelis Permusyawaratan Rakyat Republik Indonesia (MPR-RI). Konstelasi politik Indonesia yang cukup memanas ketika itu, kemudian melahirkan Ketetapan MPR Nomor XI/MPR/1998. Ketetapan tersebut kemudian menjadi landasan yuridis yang mendorong tuntutan pemberantasan $\mathrm{KKN}$ terhadap mantan Presiden Soeharto beserta kroni-kroninya, gaung teriakan tuntutan ini kemudian disambut dan bergema dimana-mana.

Klimaksnya dibentuklah Undang-undang No. 31 tahun 1999 tentang Pemberantasan Tindak Pidana Korupsi. Undang-undang ini kemudian membawa angin segar dan harapan baru dalam masyarakat. Namun validitas dan eksistensi Undang-undang No. 31 tahun 1999 tidak dapat bertahan lama. Kurang lebih dua tahun kemudian, diubah dengan Undangundang No. 20 tahun 2001 tentang Perubahan Atas Undang-undang No. 31 tahun 1999 tentang Pemberantasan Tiondak Pidana Korupsi.

Salah satu dasar dan alasan dirubahnya Undangundang No. 31 tahun 1999, disebutkan dalam penjelasannya, adalah karena korupsi di Indonesia sudah terjadi secara sistematik dan meluas sehingga tidak hanya merugikan keuangan negara, akan tetapi juga telah melanggar hak-hak sosial dan ekonomi masyarakat secara luas, maka pemberantasan korupsi perlu dilakukan dengan cara yang luar biasa. Dengan demikian, pemberantasan tindak pidana korupsi harus dilakukan dengan cara yang khusus.

Pengertian mengenai kalimat apa yang dimaksud dengan "dilakukan secara luar biasa" dan dengan "cara yang khusus," tidak ditemukan lebih lanjut dalam uraian penjelasan tersebut. Hal ini tentu saja akan memancing dan mendorong aparat penegak hukum, terutama penyidik untuk kemudian melakukan tindakan pemberantasan korupsi secara "serampangan." Lebih daripada itu sikap dan tindakan aparat penegak hukum lebih mengesankan pada sikap "arogansi" dan terlalu memaksakan kehendak hingga kemudian dapat dianggap bukan hanya telah melanggar hak-hak asasi manusia melainkan juga telah menabrak rambu-rambu hukum yang ada.

Praktek "arogansi" aparat tersebut sudah mulai terlihat dan sangat terasa sejak mulai berlakunya Undang-undang No. 20 tahun 2001 tentang Perubahan Atas Undang-Undang No. 31 tahun 1999 
tentang Pemberantasan Tindak Pidana Korupsi. Ada banyak hal yang memang sebetulnya untuk patut kita mempertanyakan kembali, diantaranya mengenai, misalnya; apakah pantas untuk dijaga dan diawasi secara langsung oleh petugas atas setiap pemberian sukarela, ketika seorang pejabat atau anak pejabat yang sedang melangsungkan resepsi pernikahan, dengan mana kemudian petugas pun dengan sigap melakukan pemeriksaan pencatatan dan merekam atas semua pemberian para undangan tersebut, padahal dasar pemberiannya adalah sukarela.

Sama halnya juga dengan suatu perbuatan hukum dalam bentuk permohonan dan pemberian kredit oleh suatu bank yang sebahagian sahamnya milik pemerintah, terhadap nasabahnya. Apakah tindakan hukum dari seorang pejabat bank (BUMN) dalam hal mengambil kebijakan pemberian kredit dimaksud dapat langsung dikategorikan dan dianggap sebagai perbuatan kejahatan korupsi. Begitu pula dengan kebijakan pemerintah dalam memberikan Bantuan Likuiditas Bank Indonesia (BLBI) terhadap bank-bank swasta nasional yang ketika itu "terpaksa" menerima kucuran Bantuan Likuiditas Bank Indonesia (BLBI).

Salah satu kasus perbankan yang paling menonjol adalah kasus E.C.W Neloe, dkk., dalam hal pemberian fasilitas kredit investasi (bridging loan), sejumlah USD.18.500.000,- atau setara dengan Rp. 160.000.000.000,- (seratus enam puluh milyar rupiah) oleh PT. Bank Mandiri (Persero), Tbk., kepada PT. Cipta Graha Nusantara (PT.CGN) / PT.Tahta Medan.

Perkara ini kemudian diputus oleh Pengadilan Negeri Jakarta Selatan pada tanggal 20 Februari 2005 (No.2068/ Pid.B/2005/PN.Jak.Sel) dengan amar putusannya antara lain, sebagai berikut: (1). Menyatakan bahwa para terdakwa, E.C.W. Neloe, I. Wayan Pugeg dan M. Sholeh Tasripan, SE. MM, tersebut, tidak terbutkti secara sah dan meyakinkan bersalah melakukan perbuatan pidana sebagaimana yang didakwakan kepada mereka; (2). Membebaskan para terdakwa tersebut dari seluruh dakwaan;(3). Memerintahkan agar para terdakwa dibebaskan dari tahanan negara; (4). Mengembalikan hakhak para terdakwa dalam kedudukan, kemampuan, harkat dan martabatnya.

Kebebasan yang diperoleh E.C.W. Neloe, dkk., nyatanya tidak dapat berlangsung lama. Jaksa Penuntut Umum (JPU) kemudian melakukan upaya
Kasasi ke Mahkamah Agung Republik Indonesia (MA-RI).

Melalui amar putusan Kasasi No. 1144 K/ Pid/2006, MA-RI antara lain menyatakan, mengadili : Menolak permohonan kasasi dari para Pemohon Kasasi I/para Terdakwa:(I). EDWARD CORNELLIS WILLIAM NELOE, (II). I WAYAN PUGEG, (III). M. SHOLEH TASRIFAN, SE, MM tersebut; Mengabulkan permohonan kasasi dari Pemohon Kasasi II : JAKSA/ PENUNTUT UMUM PADA KEJAKSAAN NEGERI JAKARTA SELATAN tersebut; Membatalkan putusan Pengadilan Negeri Jakarta Selatan No. 2068/Pid.B/2005/ PN.Jak.Sel, tanggal 20 Februari 2006 ;

MENGADILI SENDIRI: (1). Menyatakan para Terdakwa : I. EDWARD CORNELLIS WILLIAM NELOE, II. I WAYAN PUGEG, III. M. SHOLEH TASRIFAN, SE, MM telah terbukti secara sah dan meyakinkan bersalah melakukan tindak pidana : "Korupsi secara bersama-sama dan berlanjut"; (2). Menjatuhkan pidana oleh karena itu kepada Terdakwa-Terdakwa I, II, III, tersebut dengan pidana penjara masing-masing selama 10 (sepuluh) tahun; (3). Menetapkan lamanya Terdakwa-Terdakwa I, II, III berada dalam tahanan sebelum putusan ini mempunyai kekuatan hukum tetap, akan dikurangkan seluruhnya dari pidana penjara yang dijatuhkan; (4). Menghukum Terdakwa-Terdakwa I, II, III dengan hukuman denda masingmasing sebesar Rp. 500.000.000,- (lima ratus juta rupiah) dengan ketentuan apabila pidana denda tidak dibayar, maka kepada masing-masing Terdakwa dikenakan hukuman pengganti berupa pidana kurungan selama 6 (enam) bulan;

Putusan MA-RI ini kemudian mendapat tanggapan beragam dari kalangan pakar hukum maupun masyarakat. Banyak pihak yang pro namun tidak sedikit pula yang contra dengan putusan tersebut. Terlepas dari semua itu, penulis hanya melihat dan mengingatkan bahwa dampak akibat dari putusan tersebut sangat luar biasa. Setidak-tidaknya telah menimbulkan kekuatiran yang luarbiasa dikalangan investor baik dalam negeri maupun asing, untuk menggunakan semua fasilitas kredit yang ditawarkan oleh bank-bank yang sebahagian sahamnya dipegang pemerintah (BUMN). 
Para Investor selalu kuatir apabila kredit yang dipinjamnya tidak dapat dikembalikan, maka nasibnya akan sama dengan E.C.W Neloe, dkk., Padahal keterlambatan atau kegagalan pengembaliannya bukan semata-mata disebabkan penggunaannya yang tidak benar atau menyimpang, melainkan ada faktor-faktor eksternal (efect domino) dari pengaruh krisis ekonomi kawasan regional maupun internasional. Sedangkan pada aspek lain, justru sebaliknya, dengan adanya putusan MA-RI ini, baik secara langsung maupun tidak langsung, telah ikut mendorong dan "menciptakan keuntungan" yang sangat besar bagi bank-bank swasta nasional maupun asing. Bank BUMN malah kesulitan dan tidak mampu melakukan kompetitif dengan bank swasta asing.

Kedaan yang tidak berimbang ini, apabila tidak disadari, maka pelan namun pasti akan membuat keadaan perekonomian kita semakin jauh dari harapan dan makin terpuruk.

Proses penegakan hukum mutlak diperlukan. Hanya saja yang perlu digaris bawahi adalah penegakan hukum yang sesuai dengan norma-norma hukum yang berlaku dan bukan dengan dorongan hasrat pembalasan semata (lex talionis). Sebab dengan melakukan penegakan hukum yang "arogan dan serampangan" justru akan dapat menimbulkan rasa antipati dan persoalan hukum baru yakni adanya ketidakpastian hukum (onrechtzekerheids).

Norma hukum dalam ketentuan Pasal 14 Undang-undang No. 31 tahun 1999 jo Undangundang No. 20 tahun 2001 tentang Pemberantasan Tindak Pidana Korupsi, disebutkan bahwa: "setiap orang yang melanggar ketentuan Undang-undang yang secara tegas menyatakan bahwa pelanggaran terhadap ketentuan Undang-undang tersebut sebagai tindak pidana korupsi berlaku ketentuan yang diatur dalam Undang-undang ini." Dimana dalam Penjelasan Pasal 14 UU No. 31 tahun 1999, telah dijelaskan bahwa; "yang dimaksud dengan 'ketentuan yang berlaku dalam Undang-undang ini' adalah baik hukum pidana materiil maupun hukum pidana formil."

Andi Hamzah, menyebutkan bahwa Pasal 14 sebagai peraturan blangko; "ini namanya peraturan blangko yang setiap saat dapat diisi oleh legislatif dan dikategorikan sebagai perbuatan korupsi. "10

10 Andi Hamzah. "Pemberantasan Korupsi Me- lalui Hukum Pidana Nasional Dan Internasional.” Edisi Revisi. Raja Drafindo Persada, Jakarta, 2007, hlm. 119.
Norma yang terkandung dalam Pasal 14 UU No. 31 tahun 1999 jo UU No. 20 tahun 2001 adalah norma yang pasti, sudah sangat jelas dan tegas. Sehingga tidak perlu ditafsirkan lain, selain pada apa yang tertulis dalam pasal tersebut. Peraturan hukum Pasal 14 tersebut, sudah jelas dimaksudkan untuk "memagari" kedudukan Undang-undang Pemberantasan Tindak Pidana Korupsi. Dengan demikian maka sepatutnya harus dipandang sebagai norma yang membatasi dan sekaligus untuk mencegah Undang-undang Pemberantasan Tindak Pidana Korupsi sebagai "All Embracing Act dan All Purpose Act."

Indriyanto Seno Adji ${ }^{11}$ menuturkan bahwa semua perbuatan yang menyimpangi aturan tentunya diartikan sebagai perbuatan melawan hukum, tetapi tidak dapat diartikan sebagai sebuah perbuatan koruptif. Asas Kekhususan Sistematis (Systematische Specialiteit) merupakan sarana untuk mencegah dan membatasi serta meluruskan kembali arah asas perbuatan melawan hukum dan menyalahgunakan wewenang dalam tindak pidana korupsi. Hal inilah yang menarik penulis untuk melakukan pengkajian dan penelitian hukum secara ilmiah dan mendalam guna mendapatkan suatu jawaban yang mendasar dan sesungguhnya sesuai dengan norma-norma hukum pidana.

Cukup beralasan untuk kembali mempertanyakan perihal dasar dan landasan hukum atas tindakan aparat dalam menerapkan hukum perkara tindak pidana korupsi. Sebab seringkali dan tidak segansegan pihak aparat penegak hukum secara sengaja maupun tidak sengaja sudah bertindak diluar batas kewenangan yang dimilikinya, termasuk dan tidak terkecuali dalam hal mengeyampingkan ketentuan hukum Pasal 14 UU No. 31 tahun 1999 jo UU No. 20 tahun 2001.

Berkaitan dengan pendapat dan alasan tersebut diatas, maka memandang perlu untuk melakukan pengkajian yang rinci dan mendalam mengenai

\footnotetext{
11 Indriyanto Seno Adji. "Kendala Administrative Penal Law Sebagai Tindak Pidana Korupsi \&

Pencucian Uang." Makalah: disampaikan sebagai Sumbangsih Tulisan untuk Seminar Pertemuan Ilmiah dengan tema "Penanganan Tindak Pidana Kehutanan \& Tindak Pidana Pencucian Uang Dalam Perspektif Tindak Pidana Korupsi." Pada Hari Bhakti Adhyaksa (HBA) ke -47 tanggal 22 Juli 2007 Kejaksaan Agung R.I. Pada hari Senin, tanggal 16 Juli 2007 Jam 09-Jam 13.30 WIB di Sasana Pradana Kejaksaan Agung R.I., Jakarta Selatan.
} 
ruanglingkup dan kedudukan Undang-undang No. 31 tahun 1999 jo UU No. 20 tahun 2001 terhadap Undang-undang khusus lainnya, serta bagaimana seharusnya mejalankan fungsi hukum UU No. 31 tahun 1999 jo UU No. 21 tahun 2001, sebagai asas Kekhususan Sistematis (Systematische Specialiteit) terhadap dimensi kedudukan hukum khusus lainnya, dalam hal ini Undang-undang Administrasi bersanksi pidana atau adiministrative penal law yang juga berasaskan lex specialis sistematic lege generale.

Dilihat dari perspektif kebijakan legislasi hukum pidana maka terminologi "administrative penal law" adalah semua produk legislasi berupa peraturan perundang-undangan yang tercakup dalam ruang lingkup administrasi negara yang memiliki sanksi pidana. Produk legislasi demikian seperti, Undang-undang Perbankan, Undang-undang Pajak, Undang-undang Lingkungan Hidup, Undang-undang Perikanan, Undang-undang Pertambangan, Undangundang Kehutanan, Undang-undang Keuangan, Undang-undang Pasar Modal, Undang-undang Ketenagalistrikan, Undang-undang Telekomunikasi, dan lain-lain merupakan dimensi "administrative penal law" sepanjang dalam Undang-undang tersebut telah diatur ketentuan yang ada sanksi pidananya. Oleh karena itu, maka perbuatan yang dipandang merupakan pelanggaran terhadap perundang-undangan administrasi lazim disebut dengan Tindak Pidana Perbankan, Tindak Pidana Lingkungan Hidup, Tindak Pidana Pajak, Tindak Pidana Kehutanan, dan lain sebagainya. ${ }^{12}$

Dari dimensi demikian maka adanya sanksi pidana yang terdapat di dalam "administrative penal law" lazimnya menimbulkan persoalan baru dikaji dari perspektif normatif, teoritik dan praktik peradilan. Di satu sisi, apakah produk demikian tersebut masuk dalam ruang lingkup hukum administrasi negara sehingga sanksi diterapkan kepada pelanggarnya merupakan dimensi administrasi negara ataukah tidak. Sedangkan di sisi lainnya, apakah dimensi "administrative penal law" bukan merupakan dimensi hukum administrasi

\footnotetext{
12 Parman Soeparman, Dimensi 'Administrative Penal Law'Sebagai Tindak Pidana Korupsi, Makalah: disam- paikan dalam RAKERNAS Mahkamah Agung RI dengan Jaja- ran Pengadilan, Empat Lingkungan Peradilan Seluruh Indonesia Tahun 2007 di Makassar, 2-6 September 2007.
}

negara akan tetapi, melainkan merupakan ranah dari penegakan hukum pidana sehingga bagi pelanggarnya akan dikenakan sanksi pidana. ${ }^{13}$

Oleh karena itu, maka persoalan multi kriminalisasi yang bersifat khusus tersebut, sebagaimana telah disebutkan diatas yaitu adanya tindak pidana perbankan, tindak pidana pajak, tindak pidana kehutanan, tindak pidana kehutanan yang berdimensi sebagai tindak pidana korupsi memang merupakan persoalan baru yang memerlukan pemecahan secara mendalam. Persoalan gradual dan substansi fundamental muncul dari dimensi tersebut, yaitu; apakah pelanggaran terhadap "administrative penal law" dapat diklasifikasikan sebagai tindak pidana korupsi karena adanya suatu perbuatan materiil (materiele daad) adalah sama, dalam perspektif pelanggaran beberapa perundangundangan. ${ }^{14}$

Berdasarkan hal-hal sebagaimana yang sudah diuraikan tersebut diatas, guna dapat memahami makna yuridis dan kebenaran dalam penerapan hukum, maka diperlukan adanya suatu langkah pengkajian strategis, terukur dan dapat dipertanggungjawabkan. Disamping itu diharapkan pula, agar penelitian dan penulisan karya ini, kiranya mampu menjawab dan mejelaskan sampai sejauh mana kompetensi dan ruang lingkup dimensi kewenangan dari masing-masing Ketentuan Undangundang khusus (lex specialis derogat lege generale) dalam hal ini Undang-undang Pemberantasan Tindak Pidana Korupsi terhadap Undang-undang khusus lainnya; adminitrative penal law, yang berasaskan lex specialis systematic derogat lege generale. Hal inilah yang kemudian menjadi pertimbangan dan pilihan judul dalam penulisan ini.

Bagaimana Kedudukan atau Kompetensi Hukum Undang-undang No. 31 tahun 1999 jo Undang- undang No. 20 tahun 2001 tentang Pemberantasan Tindak Pidana Korupsi (lex specialis derogat lege generale) terhadap Dimensi Hukum Administrasi Bersanksi Pidana (lex specialis systematic derogat lege generale).

Bagaimana implementasi Asas Kekhususan

$13 \quad$ Ibid

14 Ibid


Sistematis (Systematische Specialiteit) sebagaimana Ketentuan Pasal 14 Undang-Undang No. 31 tahun 1999 jo Undang-undang No. 20 tahun 2001 tentang Pemberantasan Tindak Pidana Koruspi.

Memahami Hukum pemberantasan tindak pidana korupsi selaku hukum khusus terhadap dimensi kedudukan hukum khusus lainnya, dalam hal ini hukum administrasi bersanksi pidana (administra- tive penal law). Diharapkan pula bahwa agar tu- juan penerapan hukum akan menjadi lebih terukur, efektif, tertib, bermanfaat dan berkeadilan.

Mengetahui proses dan pola implementasi ketentuan Pasal 14 Undang-undang No. 31 tahun 1999 jo Undang-Undang No. 20 tahun 2001 tentang Pemberantasan Tindak Pidana Korupsi. Truth seeking hanya dapat dicapai secara maksimal apa- bila konsisten dalam menerapkan norma hukum.

\section{Pembahasan}

\section{Pemberantasan Tindak Pidana Korupsi}

Cicero pernah mengatakan; "ubi societas ibi ius" yang berarti "di mana ada masyarakat, di situ ada hukum." Artinya masyarakat tidak dapat dipisahkan dari hukum, karena memang diperlukan untuk mengatur masyarakat itu sendiri.

Ungkapan senada pernah juga disampaikan oleh Von Savigny, dengan inti ajarannya; Recht Wird nicht gemach, est ist und mit dem Volke - hukum itu tidak dibuat, tetapi tumbuh dan berkembang bersama masyarakat. Dalam pandangannya bahwa didunia ini terdapat banyak bangsa, dan tiap-tiap bangsa tadi memiliki suatu Volksgeist-jiwa rakyat. Jiwa ini berbeda berbeda, baik menurut waktu maupun tempat. Tidaklah masuk akal kalau terdapat hukum yang sifatnya universal dan abadi. ${ }^{15}$

Kedua teori tersebut diatas, merupakan suatu landasan berpikir umum yang hendak mengingatkan dan menjelaskan bahwa setiap masyarakat, bangsa dan negara memiliki warna dan corak hukum dan kebiasaannya sendiri. Setiap masyarakat bangsa mempunyai falsafah dan jiwanya sendiri, dan karenanya setiap negara membutuhkan kekhasan hukumnya yang tentunya berasal, tumbuh dan berkembang menurut perilaku masyarakat dan kebudayaan bangsa itu sendiri. Hukum

15 Lili Rasjidi dan Ira Thania Rasjidi, "Pengan-tar Filsafat

Hukum.” Mandar Maju, Bandung, 2002, hlm. 63. yang berasal dari, oleh dan untuk masyarakat ini kemudian digunakan untuk mengatur ketertiban, memperkokoh landasan bangsa dan menjadi pedoman dalam menentukan arah dan tujuan suatu bangsa. Disamping itu, penulis juga menggunakan teori induk (grand theory) Negara Hukum dan teori terapan (applied theory) Penegakan Hukum.

Menurut ketentuan Pasal 1 ayat (3) UUD 1945 Amandemen Ketiga, Negara Indonesia merupakan Negara Hukum (rechtsstaat) yang menjamin Kepastian Hukum (rechtzekerheids)dan Perlindungan terhadap Hak Asasi Manusia (human rights). Secara teoritik konsepsi Negara Hukum Indonesia bukan dalam artian formal, melainkan dalam artia materil atau lazim dipergunakan terminologi Negara Kesejahteraan (welfare State) atau "Negara Kemakmuran." Oleh karena itu, tujuan yang hendak dicapai Negara Indonesia adalah terwujudnya masyarakat adil dan makmur baik spiritual maupun materiil berdasarkan Pancasila, sehingga "disebut juga sebagai negara hukum yang memiliki karakteristik mandiri." 16

Selanjutnya dalam perkembangan ilmu hukum, diketahui bahwa secara teoritis, dapat dijumpai kurang lebih ada tiga bentuk atau tipe negara hukum, yaitu; (1). Negara Hukum Liberal, tipe ini menghendaki supaya negara berstatus pasif, artinya bahwa warga negara harus tunduk pada peraturan-peraturan negara. Penguasa dalam bertindak sesuai dengan hukum. Disini kaum liberal mengehandaki agar antara penguasa dan yang dikuasai ada suatu persetujuan dalam bentuk hukum, serta persetujuan yang menguasai penguasa. (2). Negara Hukum Formil, sebagai negara hukum yang mendapat pengesahan dari rakyat, segala tindakan penguasa memerlukan bentuk hukum tertentu, harus berdasarkan undang-undang. Negara hukum formil ini disebut pula dengan negara demokratis yang berlandaskan negara hukum. Dalam hal ini menurut Stahl, negara hukum itu harus memenuhi 4 (empat) unsur:

1. bahwa harus ada jaminan terhadap hak-hak asasi

2. adanya pemisahan kekuasaan

3. pemerintahan didasarkan pada undang-undang

4. harus ada peradilan administrative, dan selanjutnya

\footnotetext{
16Rukmana Amanwinata. "Pengaturan dan Batas Implementasi Kemerdekaan Berserikat Dan Berkumpul Dalam Pasal 28 UUD 1945. ' Disertasi, Fakultas Pascasarjana Universitas Padjadjaran. Bandang, 1996, hlm.109.
} 
yang terakhir (3). Negara Hukum Materil, tipe ini sebenarnya merupakan perkembangan lebih lanjut dari negara hukum formil; tindakan dari penguasa harus berdasarkan undang-undang atau harus berlaku asas legalitas, maka dalam negara hukum materil tindakan dari penguasa dalam hal mendesak demi kepentingan warga negaranya dibenarkan bertindak menyimpang dari undangundang atau berlaku asas opportunitas. ${ }^{17}$

Berdasarkan pada teori pembagian bentuk negara hukum tersebut diatas, maka andaikata kemudian dipetakan dan diletakan pada mozaik hukum nasional, maka dapatlah dikemukakan bahwa Indonesia menganut falsafah dan landasan negara hukum yang tidak hanya didominasi asas negara hukum formil semata, melainkan juga negara hukum materiil. Setiap langkah tindakan dan jenjang pengelolaan sumber daya pemerintahan, termasuk didalamnya denyut dan tindakan penguasa dalam masyarakat, begitupun sebaliknya, harus benarbenar didasarkan pada norma-norma hukum yang berlaku, sehingga diharapkan dapat tercapainya suatu jaminan kepastian hukum (rechtszekerheids) dan keadilan serta perlindungan hak asasi manusia (human rights).

Berbicara tentang pemahaman dan pengertian ciri-ciri dan konsepsi negara hukum, hal ini tidak terlepas dari pengaruh doktrin rule of law. Albert Venn Dicey menyebutkan bahwa; "Rule of Law" terdiri atas 3 (tiga) unsur yaitu; Supremasi Hukum (supremacy of law), Persamaan didepan Hukum (equality befote the law), dan Konstitusi yang didasarkan atas Hak-hak Perseorangan (the constitution based on individual rights). ${ }^{18}$

Senada dengan hal tersebut, Indriyanto Seno Adji, dengan mengutip pendapat Oemar Seno Adji, menuturkan bahwa ciri khusus Negara Hukum Indonesia yang digariskan oleh ilmu hukum melalui prinsip-prinsip "Rule of Law" yaitu; (1). pengakuan dan perlindungan terhadap hak-hak asasi yang mengandung perlakuan yang sama dibidangbidang politik, hukum, sosial ekonomi, budaya dan pendidikan; (2). legalitas dalam arti hukum dalam

17 C. S. T. Kansil dan Christine S. T. Kansil, "Ilmu Negara (Umum dan Indonesia)," Pradnya Paramita, Ce- takan kedua, Jakarta, 2004, hlm. 39-40.

18 Soerjono Soekanto, Beberapa Permasalahn Hukum Dalam Kerangka Pembangunan Di Indonesia (Statu Tunjauan Secara Sosiologis), Penerbit UI Press, Yakarta, 1983, hlm.65 segala bentuknya, dan (3). peradilan yang bebas, tidak bersifat memihak, bebas dari segala pengaruh kekuasaan lain. Dengan demikian tegas Oemar Seno Adji, ciri-ciri tersebut menunjukan bahwa ada persamaan prinsip yang diterapkan disemua negaranegara termasuk Amerika Serikat dibawah "Rule of Law" terutama yang digariskan oleh International Comisión of Jurist tersebut. ${ }^{19}$

Negara melalui alat kelengkapan pemerintah berkewajiban mewujudkan cita negara hukum tersebut, maka sudah sepatutnya pemerintah harus melayani masyarakat (public service) dan memberikan kesejahteraan bagi seluruh rakyatnya. Selain itu, sebagai penganut falsafah negara hukum, Pemerintah juga berkewajiban untuk menegakan supremasi hukum dengan merapkan asas legalitas dan penegakan hak-hak asasi manusia. Pemerintah dan masyarakat wajib tunduk dan taat pada semua aturan dan ketentuan hukum yang berlaku. Konkritnya, masyarakat maupun pemerintah tidak boleh bertindak sendiri-sendiri dan sewenangwenang, semua pola tindakan tanpa kecuali, harus dilakukan mengikuti dan benar-benar berdasarkan pada ketentuan hukum.

Hal senada juga dikemukakan, Purwoto S. Gandasubrata, bahwa Indonesia harus memenuhi tiga asas pokok negara hukum, yaitu:

1. asas supremasi hukum atau asas legalitas, dimana penguasa dan setiap penduduk/ warganegara harus tunduk dan taat kepada hukum.

2. asas mengakui dan melidungi hak asasi manusia dan perikemanusiaan yang adil dan beradab.

3. adanya kekuasaan kehakiman yang merdeka (an independent yudiciary) yang mampu menegakan supremasi hukum dan hak asasi manusia apa- bila terjadi pelanggaran/sengketa hukum dalam masyarakat. ${ }^{20}$

\section{Dengan demikian maka menjadi elemen}

19 Indriyanto Seno Adji, "Freedom \& Importial of Judiciary" yang sетu? Makalah disampaikan pada seminar "Kemandirian Kekuasaan Kehakiman di Masa Depan dalam Rangka Reformasi Hukum," yang diselenggarakan dalam rangka Hari Ulang Tahun Ikatan Hakim Indonesia (IKAHI) ke-53, Se- lasa 14 Maret 2006 di Hotel Bumi Karsa Bidakara, Jakarta. Vide Majalah Hukum Varia Peradilan Tahun ke XXI No.244, Maret 2006, hlm.28.

20Purwoto S. Gandasubrata, Kedudukan Keku- asaan Kehakiman Menurut UUD 1945 Dalam Negara Hukum Indonesia, Varia Peradilan tahun XVI No.182, Nopember 2000, hlm.135. 
terpenting dari strategi penegakan hukum, supremacy of law dan equality before the law akan merupakan acuan dan dasar penilaian yang konstan dalam bidang penegakan hukum. Artinya penerapan atau penegakan hukumnya harus selalu dapat dipertanggungjawabkan, taat asas, tertib dan benarbenar dilakukan secara terukur, konsisten, murni dan konsekuen.

\section{Penegakan Hukum Dan Penerapan Pera- turan Perundang - Undangan}

Konsekuensi dari negara hukum, maka paling tidak, ada tiga prinsip dasar yang wajib dijunjung oleh aparat pemerintah dan setiap warga negara, yakni; supremasi hukum (supremacy of law), kesetaraan dihadapan hukum (equality before the law) dan proses penegakan hukum dengan cara-cara yang tidak bertentangan dengan hukum.

Dalam kaitannya dengan penegakan hukum atau "lawenforcement" sebagaimana landasan teori aplikasi atau penerapan dalam kajian ini, merupakan ujung tombak agar terciptanya tatanan hukum yang baik dalam masyarakat.

Istilah penegakan hukum menurut Soerjono Soekanto, ${ }^{21}$ adalah "kegiatan menyerasikan hubungan nilai-nilai yang terjabarkan didalam kaidah-kaidah yang mantap dan mengejawantah dari sikap tindak sebagai rangkaian penjabaran nilai tahap akhir untuk menciptakan, memelihara dan mempertahakan kedamaian pergaulan hidup."

Bertolak dari pengertian penegakan hukum tersebut diatas, maka yang dimaksud tidak lain adalah segala daya upaya untuk menjabarkan kaidahkaidah hukum kedalam kehidupan masyarakat, sehingga dengan demikian dapat terlaksana tujuan hukum dalam masyarakat berupa perwujudan nilainilai keadilan, kepastian hukum, perlidungan hak, ketertiban, kebahagian masyarakat dan lain-lain. ${ }^{22}$

Dalam kaitannya dan kerangka berpikir inilah, maka dapat dikemukakan bahwa sekalipun tindak pidana korupsi, sudah dikualifikasikan sebagai suatu kejahatan luar biasa

\footnotetext{
21 Soerjono Soekanto, "Faktor-faktor Yang Mempengaru- hi Penegakan Hukum." Pidato: pengukuhan dalam jabatan Guru Besar Tetap pada Fakultas Hukum Universitas Indonesia. Tanggal 14 Desember 1983. Jakarta, hlm.2

22 Ahmad Mujahidin, “Peradilan Satu Atap di Indonesia.” Rafika Aditama. Bandung, 2007, hlm 181
}

(extra ordinary crime), bukan berarti dalam setiap pemberantasannya pun harus/ dapat dilakukan dengan menghalalkan segala cara atau dengan sengaja mengenyampingkan norma-norma hukum lainnya. Semua tindakan termasuk dan tidak terkecuali dalam hal melakukan pemberantasan tindak kejahatan termasuk didalamnya pidana korupsi wajib tunduk dan mengikuti prosedur hukum yang berlaku. Penerapan norma Undang-undang Pemberantasan Tindak Pidana Korupsi, seharusnya dan sepatutnya dilakukan secara terukur, konsisten dan profesional oleh setiap pilar aparat penegak hukum, baik jaksa, polisi dan hakim maupun advokat. ${ }^{23}$ Setiap tindakan aparat penegak hukum tersebut, harus tetap berdasar dan mengacu pada prosedur hukum yang berlaku, termasuk namun tidak terbatas dalam penerapan peraturan hukum sebagaimana yang dirumuskan dan tercantum dalam Pasal 14 Undang-undang No. 31 tahun 1999 jo Undang-undang No. 20 tahun 2001

Peraturan hukum dalam Pasal 14 UU No. 31 tahun 1999 jo UU No. 20 tahun 2001, menyebutkan bahwa ; "setiap orang yang melanggar ketentuan Undang-undang yang secara tegas menyatakan bahwa pelanggaran terhadap ketentuan Undangundang tersebut sebagai tindak pidana korupsi berlaku ketentuan yang diatur dalam Undangundang ini."

Mencermati susunan dan rumusan peraturan hukum dalam pasal tersebut diatas, sepatutnya hal ini tidak lagi dapat ditafsirkan lain, selain norma yang terkandung didalamnya. Artinya norma hukum yang terkandung dalam Pasal 14 tersebut sudah final, sangat jelas dan tegas telah membatasi kedudukan dan wewenang hukum Undang-undang No. 31 tahun 1999 jo UU No. 20 tahun 2001. Pembatasan norma tersebut dimaksudkan agar Undang-undang Pemberantas Tindak Pidana Korupsi tidak menjadi "All Embracing Act" dan " All Purpose Act."

Ihering, ${ }^{24}$ dengan tegas menolak gagasan hukum berlaku secara universal. Hukum yang tidak

\footnotetext{
23 Republik Indonesia, Pasal 5 aya (1) UU. No.18 tahun 2003 tentang Advokat, menyebutkan bahwa Advokat bers- tatus sebagai penegak hukum, bebas dan mandiri yang dijamin oleh hukum dan peraturan perundang-undangan.

24 W. Friedmann, "Teori dan Filsafat Hukum, Telaah Kri- tis Atas Teori-Teori Hukum (Susunan 1-2-3)," Diterjemahkan dari buku aslinya Lega Theory, oleh Mohamad Arifin, Rajawali, Cetakan Pertama, Jakarta, 1990, hal.38
} 
dibatasi oleh ruang dan waktu, sebagai; "tidak lebih baik dari pada perlakuan medis yang sama bagi semua pasien." Dengan diperlakukan secara seragam atau universal, maka dengan sendirinya akan menimbulkan kontra produktif yang pada gilirannya akan menimbulkan suatu dilema baru, yakni ketidakpastian hukum (onrechtzekerheid).

Selain hal tersebut, dalam Kitab UndangUndang Hukum Pidana (KUHP) Pasal 63 ayat (1) telah ditentukan dan ditegaskan bahwa; "jika suatu perbuatan masuk dalam lebih dari satu aturan pidana, maka yang dikenakan hanya salah satu diantara aturan-aturan itu, jika berbeda-beda, yang dikenakan yang memuat ancaman pidana pokok yang paling berat." (asas concursus idealis). Di dalam ayat (2) ditegaskan lebih jauh, bahwa; "jika suatu perbuatan, yang masuk dalam suatu aturan pidana yang umum, diatur pula dalam aturan pidana yang khusus, maka hanya yang khusus itulah yang dikenakan."

Berdasarkan peraturan hukum tersebut diatas, sepatutnya terhadap setiap perbuatan pelanggaran atau penyimpangan-penyimpangan yang terjadi dalam ruang lingkup hukum adminstrasi penal law, sebagaimana diatur dalam ketentuan dan peraturan hukum, antara lain misalnya Undang-undang Perbankan, Pajak, Kehutanan, Pencucian Uang dan lain-lain, maka semestinya pola pendekatan yang digunakan untuk menindaknya cukup dilakukan dengan peraturan hukum yang terdapat pada domain Undang-undang tersebut (Administrative Penal Law). Sebab apabila kemudian, terhadap pelanggaran dalam peraturan hukum Perbankan, Pajak dan lain-

lain, oleh aparat diterapkan dengan menggunakan penerapan peraturan hukum Pemberantasan Tindak Pidana Korupsi, maka praktek inilah sesungguhnya yang dinamakan dengan pemberlakuan secara umum (universal). Hal yang demikian ini tentu tidak sejalan dengan maksud yang terkandung dalam Pasal 14 UU. No. 31 tahun 1999 jo UU No. 20 tahun 2001, bagaikan melakukan tindakan medis dengan melakukan perawatan serta penggunaan obat yang sama (diseragamkan) terhadap semua pasien disuatu rumah sakit.
Romli Atmasasmita, ${ }^{25}$ menyatakan bahwa langkah penegakan hukum pemberantasan korupsi merupakan kewajiban bersama bukan hanya penegak hukum melainkan juga seluruh komponen bangsa dengan bimbingan dan tauladan para pemimpin bangsa ini mulai dari Presiden selaku kepala negara dan kepala pemerintahan, wakil presiden sampai kepada pimpinan birokrasi di daerah, lembaga legislatif dan judikatif. Tidak kurang pentingnya peranan masyarakat sipil (civil society-cso) dalam mendorong, monitoring dan evaluasi keberhasilan pemberantasan korupsi. Namun demikian sesuai dengan landasan yuridis terutama UUD 1945 khususnya berkaitan dengan hak asasi setiap warga negara (Bab XA Pasal 28 D), ${ }^{26}$ maka langkah penegakan hukum pemberantasan korupsi juga seharusnya dapat menjamin dan memelihara proteksi terhadap hak asasi tersangka dan terdakwa serta terpidana korupsi, selain peningkatan efektivitas dan keberhasilan pemberantasan korupsi itu an sich!

Politik hukum dalam rangka penegakan dan penerapan hukum nasional dibutuhkan harmonisasi dan refungsionalisasi dalam implementasinya, sehingga hukum nasional dapat ditegakan dan diterapkan secara tertib, terukur, sistematis, konsisten dan profesional, yang kemudian pada gilirannya diharapkan akan dapat membawa kepada suatu tujuan Kemanfaatan, Kepastian Hukum (rechtzekerheid), dan Keadilan. 


\section{Kesimpulan dan Saran}

Indonesia sebagai Negara Hukum sebagaimana di muat dalam Pasal 1 ayat (3) UUD 1945 hasil Amandemen ketiga, Negara Indonesia merupakan Negara Hukum (rechtsstat), yang menjamin kepastian hukum (rechtzekerheids), dan Perlindungan terhadap Hak Asasi Manusia. Tujuan yang hendak dicapai oleh Indonesia adlah terwujudnya masyarakat adil dan makmur baik secara spiritual maupun secara materiil berdasarkan Pancasila, sehingga disebut juga sebagai Negara Hukum yang memiliki karakteristik mandiri”. Sekalipun Tindak pidana korupsi sudah dikualifikasikan sebgai kejahatan luar biasa, bukan berarti dpat dilakukan dengan menghalalkan segala cara atau dengan sengaja mengeyampingkan norma - norma hukum lainnya. Semua tindakan tidak terkecuali dlam hal melakukan pemberantasan tindak kejahatan termasuk di dalamnya pidana korupsi wajib tunduk dan mengikuti prosedur hukum yang berlaku. Setiap tindakan aparat penegak hukum harus tetap berdasarkan prosedur hukum yang berlaku, dan penerapan norma Undang - undang Pemberantasan Tindak Pidana Korupsi, seharusnya dan sepatutnya dilakukan secara terukur, konsisten dan profesional.

Penegakan hukum hendaknya jangan dilakukan dengan cara arogan dan serampangan, sehingga dapat menimbulkan rasa antipati, dan persoalan hukum baru. Pemerintah berkewajiban melayani masyarakat (public service), dan memberikan kesejahteraan bagi seluruh rakyatnya, dan Pemerintah wajib meneggakkan supremasi hukum, masyarakat maupun pemerintah tidak boleh bertindak sendiri-sendiri, dan sewenangwenang harus dilakukan berdasarkan ketentuan hukum.

\section{DAFTAR PUSTAKA}

\section{Buku-Buku}

Ahmad Mujahidin, "Peradilan Satu Atap di Indonesia.” Rafika Aditama. Bandung, 2007

Andi Hamzah, "Pemberantasan Korupsi Melalui Hukum Pidana Nasional Dan Internasional." Edisi Revisi. Raja Grafindo Persada, Jakarta, 2007.

Barda Nawawi Arief, "Beberapa Aspek Kebijakan Penegakan dan Pengembangan Hukum Pidana." Citra Aditya Bakti, Cetakan II, Semarang, 2005.

C. S. T. Kansil dan Christine S. T. Kansil, "Ilmu Negara (Umum dan Indonesia) " Pradnya Paramita, Cetakan kedua, Jakarta 2004.

Indriyanto Seno Adji, “Korupsi Kebijakan Aparatur Negara \& Hukum Pidana, Diadit Media, Jakarta, 2007.

Lili Rasjidi dan Ira Thania Rasjidi, "Pengantar Filsafat Hukum” Mandar Maju, B andung, 2002.

Mohammad Amien Rais, "Agenda-Mendesak Bangsa Selamatkan Indonesia" PPSK Pres, Cetakan Ketiga, Yogyakarta, 2008.

Purwoto S. Gandasubrata, "Kedudukan Kekuasaan Kehakiman Menurut UUD 1945 Dalam Negara Hukum Indonesia," Varia Peradilan tahun XVI No.182, Nopember 2000.

Roscoe Pound, "Interpretation of Legal History", Wm. W. Gaunt \& Sons Inc, Flo rid a, 1986.

Soerjono Soekanto, "Beberapa Permasalahn Hukum Dalam Kerangka Pembangunan Di Indonesia (Statu Tunjauan Secara Sosiologis), " Penerbit UI Press, Jakarta, 1983. dan Sri Mamudji, "Penelitian Hukum Normatif Suatu Tinjauan Singkat" Penerbit Rajawali, Jakarta, 1990.

Sunaryati Hartono, "Penelitian Hukum di Indonesia Pada Akhir Abad ke20. ”Alumni, Bandung, 1994. 
W. Friedmann, "Teori dan Filsafat Hukum,Telaah Kritis Atas Teori-Teori Hukum (Susunan 1-2-3)." Diterjemahkan dari buku aslinya "Legal Theory" oleh Mohamad Arifin, Rajawali, Cetakan Pertama, Jakarta, 1990.

\section{Makalah, Jurnal dan Artikel Media Masa}

Indriyanto Seno Adji, "Kendala Administrative Penal Law Sebagai

Tindak Pidana Korupsi \& Pencucian Uang. " Makalah: disampaikan sebagai Sumbangsih Tulisan untuk Seminar Pertemuan Ilmiah dengan tema "Penanganan Tindak Pidana Kehutanan \& Tindak Pidana Pencucian Uang Dalam PerspektifTindak Pidana Korupsi." Pada Hari Bhakti Adhyaksa (HBA) ke -47 tanggal 22 Juli 2007 Kejaksaan Agung R.I. Pada hari Senin, tanggal 16 Juli 2007 Jam 09-Jam 13.30 WIB di Sasana Pradana Kejaksaan Agung R.I., Jakarta Selatan.

"Freedom \& Importial of

Judiciary" yang semu? Makalah disampaikan pada seminar "Kemandirian Kekuasaan Kehakiman di Masa Depan dalam Rangka Reformasi Hukum,"yang diselenggarakan dalam rangka Hari Ulang Tahun Ikatan Hakim Indonesia (IKAHI) ke53, Selasa 14 Maret 2006 di Hotel Bumi Karsa Bidakara, Jakarta. Vide Majalah Hukum Varia Peradilan Tahun ke XXI No.244, Maret 2006.

Parman Soeparman, "Dimensi 'Administrative Penal Law'Sebagai Tindak Pidana Korupsi," Makalah disampaikan dalam RAKERNAS Mahkamah Agung RI dengan Jajaran Pengadilan, Empat Lingkungan Peradilan Seluruh Indonesia Tahun 2007 di Makassar, 2-6 September 2007.

Robert Klitgaard, “Corrupt Custom”, sebagaimana dikutip Mardjono Resodiputro, Tanggapan Atas Kajian Laboratorium Sosiologi FISIP-UI tentang "Performance Review" atas Tim Gabungan Pemberantasan Tindak Pidana Korupsi (TG-TPK), Catatan diskusi disampaikan dalam Seminar Tim Gabungan Pemberantasan Tindak
Pidana Korups, yang diselenggarakan oleh Laboratorium Sosiologo FISIP-UI, Jakarta 25 Juli 2001.

Romli Atmasasmita, "Strategi dan Kebijakan Hukum Dalam Pemberantasan Korupsi Melawan Kejahatan Korporasi di Indonesia: Membentuk Ius Constituendum Pasca Ratifikasi Konvensi PBB Menentang Korupsi Tahun 2003. ” (Pa- per), Jakarta 2006.

------------------- , “Politik Hukum

Pemberantasan Korupsi: Lex Specialis

Systematic Versus Lex specialis Derogat Lege Generale." [Artikel ini disusun sebagai reaksi atas artikel, Sudjono Iswahyudi, $\mathrm{SH}$, "Putusan MA dan Pemberantasan Korupsi"; dimuat dalam harian Media Indonesia tanggal 15 Oktober 2007, Vide WWW.Legalitas.org, diunduh tanggal 1 Agustus 2008.

Rukmana Amanwinata, "Pengaturan dan Batas Implementasi Kemerdekaan Berserikat Dan Berkumpul Dalam Pasal 28 UUD 1945." Disertasi, Fakultas Pascasarjana Universitas Padjadjaran. Bandang, 1996

Soerjono Soekamto, "Faktor-faktorYang Mempengaruhi Penegakan Hukum.” Pidato: pengukuhan dalam jabatan Guru Besar Tetap pada Fakultas Hukum Universitas Indonesia. Jakarta, tanggal 14 Desember 1983

\section{Peraturan Perundang-undangan}

Republik Indonesia, Undang-Undang Dasar 1945 dan Amandemennya.

Republik Indonesia, Kitab Undang-Undang Hukum Pidana (KUHP).

Republik Indonesia, Undang-Undang No.8 tahun 1981 tentang KUHAP

Republik Indonesia, Undang-Undang No. 31 tahun 1999 tentang Pemberantasan Tindak Pidana Korupsi.

Republik Indonesia, Undang-Undang No. 20 tahun 
2001 tentang Perubahan Atas UU No.

31 tahun 1999 tentang

Pemberantasan Tindak Pidana Ko-

rupsi.

Republik Indonesia, Undang-Undang

No. 3 tahun 1971 tentang

Pemberantasan Tindak Pidana

Korupsi.

Republik Indonesia, Undang-Undang.

No. 18 tahun 2003 tentang Advokat

\section{Putusan Lembaga Peradilan}

\section{Mahkamah Konstitusi Republik}

Indonesia No. 003/ PUU-IV/2006.

Tanggal 25 Juli 2006.

Mahkamah Agung Republik Indonesia No. 1144 K/ Pid/2006. Tanggal 13 September 2007 